\title{
COMPOSITE GARNET PERIDOTITE XENOLITH FROM PICRITE-BASALT, VITIM PLATEAU (TRANS BAIKAL)! IMPLICATION FOR THE THERMOBAROMETRY AND RECONSTRUCTIONS OF THE MANTLE SECTIONS.
}

\section{V. Ashchepkov.}

Institute of Geology and Geophysics, Siberian division USSR Academy of Sciences, Novosibirsk.

In Vitim plateau garnet lherzolites were found in 01 igocene picrite-basalt tuff (Ashchepkov et al 1988) and Pliocene hawaiite cones and flows. In first location composite nodules with contact zone of different pyroxenite types are divided in several types. Green $\mathrm{Cr}$-diopside garnet websterites usually show an equilibrium with lherzolites. Their minerals are 51 ightly enriched in Al, $\mathrm{Na}$ and Ti. Two pyroxene temperatures for this veins vary within usual for garnet lherzolite interval of $950-1050 \mathrm{C}$ and $22-26$ kbar. Dark-green $\mathrm{Cr}$ and more Ti-rich branched pyroxenites occurred at lower temperatures - $900-980 \mathrm{C}$ as well as Cr-poor green clinopiroxenites containing exsolved garnet and arthopyroxene. Blue-green eclogite-like rocks forms visible reaction zones. Cr-diopside zone is changed by garnet websterite zone then substituted by garnet clinopyroxenite and then by clinopyroxenite. There is a relic trend of increasing temperature in this direction from 1020 to 1080 C. All this magmatic veins seems to be formed at the previous stages of mantle activity.

Hot pyroxenites are of two types. Green Cr-less cumulative poikilitic websterites in some cases containing rare garnet and having equilibrated temperatures about of $1200-1300 \mathrm{C}$ and pressure 27-30 kbar. The next group are presented by Ti-rich clinopyroxenites containing interstitual garnet and orthopyroxene. They occurred at the same temperature interval but at 51 ightly low pressure. This hot pyroxenites drop to the same field at TP diagram as highly deformed lherzolites which form the inflection on the estimated geotherm but direct contacts of this pyroxenite and deformed lherzolites were not found yet. The only ane found contact of such type seems to be deformed after interaction of magma with wall rock peridotites.

Last vein group containing amphibole and phlogopite may have been formed during the percolation of water saturated melts trough garnet lherzolites. Small amphibole veinlets occurred only in spinel lherzolites but phlogopite ones may be found in all peridatite rocks. They show small diffusion zoning around them. Large veins found in garnet lherzolites contain hydrous minerals. only at the central parts. The outer contacts composed by pyroxene aggregates. Their compositions suggest forming of veins in more high-temperature conditions then those of contact lherzolite associations. It is supported by break up of the garnet near the contacts.

Composite temperature equilibrated xenoliths with diffusion zonation of associated minerals allow to test the thermobarometric methods in different systems. All used thermometers (Wel15, 1977; Bertrand \& Mercier; 1985; Harley, 1984; O'Neil \& Wood, 1981; Brey and Kohler, 1990 etc.) show the coincidence of obtained data for the all part of such type of composite xenoliths within the $45 \mathrm{C}$ interval - The best of barometric methods appeared to be equation from Nickel \& Green, 1985 and Webb \& Wood, 1988 version of Wood barometer.

Reconstructed geotherm for the mantle under Vitim plateau using new data appeared several level of magma interaction with mantle wall rock lherzolites besides only one deep-seated level reported earlier (Ashchepkov et al, 1988). This points correspond to deformed and hot pyroxenites. Green types of pyraxenite xenaliths believed to be mare high temperature. 